\title{
Blindspots: Serving Your Multicultural Students
}

\author{
ReAnna Laney \\ St. Patrick's Episcopal Day School \\ 4700 Whitehaven Parkway NW \\ Washington, DC 20007 \\ U.S. A. \\ rlaney00@gmail.com
}

\begin{abstract}
Blindspots, Windows, and Mirrors
Our schools are full of multicultural families, but most popular children and young adult novels are about monocultural teens. As educators, we have a responsibility to be diverse readers -- reading books across genres featuring characters of different ethnicities, nationalities, genders, orientations, religions, and abilities, that also inspire. Yet it is challenging to present books and resources which reflect your readers and encourages them to experience a wider world. This interactive program includes criteria for diverse collections, programming and unit suggestions, and strategies for proposing changes to your curriculum. Learn how to engage your students with recent controversial topics like: whitewashed book covers, gender-flips, and genre-mashing.
\end{abstract}

Monoculturalism, Book lists, \#weneeddiversebooks, Whitewashing

\section{References}

(2014, May). Children's Books By and About People of Color. Cooperative Children's Book Center. The University of Wisconsin at Madison.

Aronson, M., and O'Brien, S. (2014, May 12). How Cross-Racial Scenes in Picture Books Builds

Acceptance. School Library Journal. School Library Journal.

Bishop, R. S. (2014, May 30). Reflections of Development of African American Children's Literature. Journal of Children's Literature, 38.2, 5-13.

Hornig, K. T. Children's Books: Still an All-White World? (2014). Retrieved June 02, 2016, 
from http://www.slj.com/2014/05/diversity/childrens-books-still-an-all-whiteworld/

Low, J. (2013). Why Hasn't the Number of Multicultural Books Increased In Eighteen Years?

Retrieved September 03, 2015, from http://blog.leeandlow.com/2013/06/17/why-hasnt-the-number-ofmulticultural-books-increased-in-eighteen-years/

St. Patrick's Episcopal Day School: Student Life. (2013). Washington, D.C. St. Patrick's Episcopal Day School. Retrieved from http://www.stpatsdc.org/

Biographical Note: ReAnna Laney is the Head Librarian at St. Patrick's Episcopal Day School in Washington D.C. Before moving to D.C., she worked in independent schools in New York City and Providence, Rhode Island. ReAnna has presented internationally, including the European Council of Independent School's Triennial Librarian Conference in Brussels, Belgium, as well as at Catholic University in Washington, D.C.. She has a passion for education technology and multicultural education. Follow ReAnna on twitter @librarystpatsdc! 